Bangladesh J. Plant Taxon. 26(1): 127-130, 2019 (June)

(C) 2019 Bangladesh Association of Plant Taxonomists

- Short communication

\title{
MYRIOPHYLLUM AQUATICUM (VELL.) VERDC. (HALORAGACEAE): A NEW ANGIOSPERMIC RECORD FOR BANGLADESH
}

\author{
Md. Almujaddade Alfasane ${ }^{1}$, Ashika Akhtar, Maliha Mehnaz, \\ Mst. Ayesha and Z.N. Tahmida Begum \\ Department of Botany, University of Dhaka, Dhaka 1000, Bangladesh
}

Keywords: Myriophyllum aquaticum (Vell.) Verdc.; Haloragaceae; New record; Bangladesh.

Freshwater Haloragaceae of Bangladesh is represented by two Myriophyllum species namely, M. tetrandrum Roxb. and M. tuberculatum Roxb. so far (Khan and Halim, 1987; Ahmed et al., 2009). The spermatophyte genus Myriophyllum is among the foremost species-rich genera of aquatic core-eudicots. Myriophyllum encompasses a cosmopolitan distribution with its centre of diversity in Australia (> thirty seven endemics). The widespread invasive species of the genus ( $M$. aquaticum, M. heterophyllum, and M. spicatum) have drawn attention from international resource managers. It is very much difficult to identify Myriophyllum species using vegetative morphology alone, which commonly is all that is available for these highly clonal plants.

The plant materials of this study were collected through a hydrobiological expedition carried out in a semi-natural lake of Bangladesh namely Madhabpur Lake located at the Madhabpur Union under Kamalganj Upazila of Moulvibazar District of Sylhet Division in the northeast corner of Bangladesh. Geographically, the lake is located between $24^{\circ} 16^{\prime} 43.154^{\prime \prime} \mathrm{N}$ to $24^{\circ} 16^{\prime} 59.1366^{\prime \prime} \mathrm{N}$ latitude and $91^{\circ} 48^{\prime} 46.163 " \mathrm{E}$ to $91^{\circ} 49^{\prime} 17.178^{\prime \prime} \mathrm{E}$ longitude (approx.) at an altitude of nearly $46 \mathrm{~m}$ above the mean sea level. This lake located at the section 11 (Patrakhala) of Madhabpur TeaEstate which is owned by National Tea Company (NTC). The current research work was carried out from May 2016 to April 2019. The sample was collected from $1 \mathrm{~m}$ depth near the shore of the lake with submerged vegetation. The plant sample was collected in a large air tight polyethylene bag with some water inside. It was transported to the Phycology, Limnology and Hydrobiology Laboratory, Department of Botany, University of Dhaka within next six hours of collection. Some fresh materials were preserved in $4 \%$ formaldehyde and few herbarium sheets of the material were prepared and preserved in this laboratory. The remaining plant sample was transferred in a concrete house $(1 \times 0.5 \mathrm{~m}$ length, depth $0.40 \mathrm{~cm})$ in the Botanical Garden, Department of Botany, University of Dhaka for culturing. The specimen has finally been identified as Myriophyllum aquaticum (Vell.) Verdc., consulting Fassett, 1957; Subramanyam, 1974; Aiken, 1981; Orchard, 1981; Sutton, 1985; Fernandez et al., 1993; Sytsma and Anderson, 1993; Les and Mehrhoff, 1999; Mabulu, 2005 and Hussner et al., 2009.

Myriophyllum aquaticum (Vell.) Verdc. was not reported earlier in the previous studies or literatures, viz. Hooker (1888), Prain (1903), Datta and Mitra (1953), Mia and Khan (1995) and Rahman (2004 a, b) from the areas that now fall under the territory of present Bangladesh. Hence, it is reported here as a new record for Bangladesh.

${ }^{1}$ Corresponding author, Email: mujaddade@du.ac.bd 
A detailed taxonomic account along with illustrations of the species has been prepared based on the fresh specimens.

Myriophyllum aquaticum (Vell.) Verdc. Kew Bull. 28: 36 (1973)

(Fig. 1)

Enydria aquatica Vell., Myriophyllum brasiliense Camb., Myriophyllum proserpinacoides Gillies ex Hook. and Arn.

Common names: Brazilian watermilfoil, parrot's feather, parrot-feather, parrotfeather, parrot feather watermilfoil

Parrot feather (Myriophyllum aquaticum) is a submerged to emergent plant that occupy different aquatic habitats. Plants perennial aquatic herbs, glabrous, with slender, sparingly branches. Stems stout and blue-green, mostly rooting freely at the lower nodes. When the submerged shoots reach the water surface, plant growth changes and begins to creep along the water surface. Extensive branches develop from nodes followed by vertical growth of emergent stems. Leaves heterophyllous, both emergent and submerged, numerous, appear feather-like and grayish green, pinnately dissected or cut into thread-like segments and arranged in whorls of 4 to 6
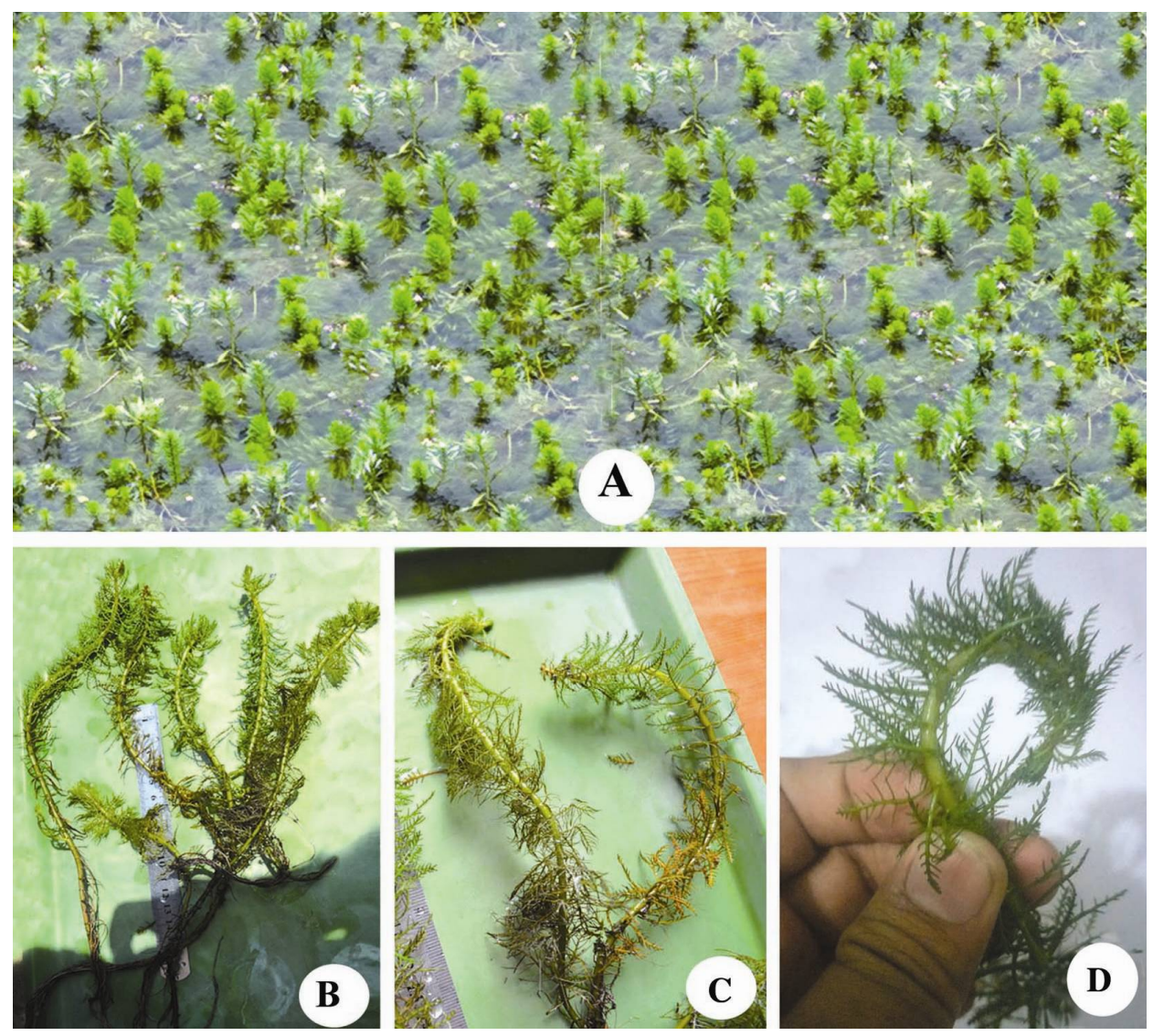

Fig. 1. A-D: A, The submerged to emergent habit of Myriophyllum aquaticum (Vell.) Verdc occupying the upper surface of the lake. B-C, Branches of the stem with whorled foliage leaves. D. The leaves cut into thread-like segments, appearing as parrot's feather. 
around the stem. The emergent leaves come out up to $25 \mathrm{~cm}$ from the water surface, $2-4.5 \mathrm{~cm}$ long and have 6-18 divisions per leaf, less divided and greener than the submerged leaves. The submerged leaves $1.5-3.0 \mathrm{~cm}$ long with 20-30 divisions per leaf. Flowers axillary, inconspicuous in the axils of the emergent leaves during the spring, in between two bracts, $1.5 \mathrm{~mm}(0.06 \mathrm{in}$.) long, apetalous, sepals white. Different species of Myriophyllum look much alike, and some are nearly impossible to distinguish without flowers or fruits.

Distribution: M. aquaticum is native to South America along the Amazon River. It has been introduced into South Africa, New Zealand, Australia, Japan and parts of Europe. It prefers to inhabit subtropical regions (Fernandez et al. 1993).

Ecology: M. aquaticum can grow in the edges of Madhabpur lake. According to Sutton (1985), this plants species were also grown in the habitats of shallow wetlands, slow moving streams, irrigation reservoirs or canals, edges of lakes, ponds, sloughs, or backwaters. $M$. aquaticum can grow in moist soil and tolerates a wide-range of water levels. It can also grow in higher water levels and high-nutrient environments (Hussner et al. 2009; Sutton, 1985; Sytsma and Anderson 1993). Numerous rooting of M. aquaticum were observed in the bottom sediments of the Madhabpur lake. M. aquaticum requires rooting in bottom sediments. Under this condition light can penetrate to the bottom of water which favour the growth of the plant and colonization.

\section{Acknowledgement}

The authors are indebted to Centre for Advanced Studies and Research in Biological Sciences, University of Dhaka for providing fund to conduct the research.

\section{References}

Ahmed, Z.U., Hassan, M.A., Begum, Z.N.T., Khondker, M., Kabir, S.M.H., Ahmad, M., Ahmed, A.T.A., Rahman, A.K.A. and Haque, E.U. (eds.) 2009. Encyclopedia of flora and fauna of Bangladesh. vol.8, Angiosperms: Dicotyledons (Fabaceae-Lythraceae). Asiatic Society of Bangladesh, Dhaka 478 pp.

Aiken, S.G. 1981. A conspectus of Myriophyllum (Haloragaceae) in North America. Brittonia 33: 57-69.

Datta, R.M. and Mitra, J.N. 1953. Common plants in and around Dacca. Bull. Bot. Soc. Beng. 7(1\&2): 1110.

Fassett, N.C. 1957. A manual of aquatic Plants. The University of Wisconsin Press, Madison, 405 pp.

Fernández, O.A., Sutton D.L., Lallana, V.H., Sabbatini, M.R., Irigoyen, J.H. 1993. Aquatic weed problems and management in South and Central America. In: A.H. Pieterse, K.J. Murphy, eds. Aquatic Weeds, 2nd Edition. Oxford University Press, Oxford, U.K. pp. 406-425.

Hooker, J.D. 1888. Flora of British India, vol.5. L. Reeve \& Co. Ltd., Kent, England. pp. 463-686.

Hussner, A., Meyer, C. and Busch, J. 2009. The influence of water level and nutrient availability on growth and root system development of Myriophyllum aquaticum. Weed Research 49: 73-80.

Khan, M.S. and Halim, M. 1987. Aquatic angiosperms of Bangladesh. Bangladesh National Herbarium, BARC, Dhaka. 120 pp.

Les, D.H., and Mehrhoff, L.J. 1999. Introduction of nonindigenous aquatic vascular plants in southern New England: a historical perspective. Biological Invasions 1(2): 281-300.

Mabulu, L.Y. 2005. Myriophyllum aquaticum (aquatic plant). Global Invasive Species Database. Available:http://www.issg.org/database/species/ecology.asp?si=401\&fr=1\&sts=sss\&lang=EN.

Mia, M.M.K. and Khan, B. 1995. First list of Angiospermic taxa of Bangladesh not included in Hooker's Flora of British India and Prain's Bengal Plants. Bangladesh J. Plant Taxon. 2(1\&2): 1-33.

Orchard, A.E. 1981. A revision of South American Myriophyllum (Haloragaceae), and its repercussions on some Australian and North American species. Brunonia 4: 27-65. 
Prain, D. 1903. (Ind. Rep. 1981). Bengal Plants, vol. 1. Bishen Singh Mahendra Pal Singh, Dehra Dun, India. 663 pp.

Rahman, M.O. 2004a. Second list of Angiospermic taxa not included in Hooker's 'Flora of British India' and Prain's 'Bengal Plants"-Series I. Bangladesh J. Plant Taxon. 11(1): 77-82.

Rahman, M.O. 2004b. Second list of Angiospermic taxa not included in Hooker's 'Flora of British India' and Prain's ‘Bengal Plants”-Series II. Bangladesh J. Plant Taxon. 11(2): 49-56.

Subramanyam, K. 1974. Botanical Monograph no. 3, Aquatic Angiosperms, A systematic account of common Indian Aquatic Angiosperms. Botanical survey of India, Calcutta, pp. 190.

Sutton, D.L. 1985. Biology and ecology of Myriophyllum aquaticum. Proceeding, 1st International Symposium on watermilfoil (Myriophyllum spicatum) and Related Haloragaceae Species. 23-24 July 1985. Vancouver, B.C. pp. 59-71.

Sytsma, M.D. and Anderson, L.W.J. 1993. Biomass, nitrogen, and phosphorus allocation in parrotfeather (Myriophyllum aquaticum). Journal of Aquatic Plant Management 31: 244-248.

(Manuscript received on 3 March, 2019; revised on 6 May, 2019) 